\title{
Biostimulation and Bioaugmentation: The Strategy of Choice in the Biodegradation of Aviation Fuel
}

\author{
Ogunsola, O.O. \& Adebusoye, S.A. \\ Department of Botany and Microbiology \\ Faculty of Science \\ University of Lagos \\ P.M.B. 56, Akoka, Yaba, Lagos State
}

\begin{abstract}
Various studies have shown that hydrocarbon contaminants are fast becoming a global menace. Many methods have been adopted for cleaning up this contaminant. The use of biostimulation and bioaugmentation have been methods of choice for bioremediation as both options are safe and cheap. In the present study, the soil of University of Lagos botanical garden was contaminated with aviation fuel and was monitored for 35 days. The soil was fortified with Minimal Salt Medium and consortium of Ralstonia sp. Strain SA4 and Pseudomonas sp. Strain SA6 separately in two microcosms. The aim of the experiment was to determine the better option for use in the case of contamination with hydrocarbons. The methods were both effective as both microcosms displayed a magnitude of reduction in the aviation oil content between days 0 and 35. The soil seeded with consortium of Ralstonia sp. Strain SA4 and Pseudomonas sp. Strain SA6, showed $80 \%$ degradation rate while that fortified with MSM showed $77 \%$ degradation rate. However, the result showed bioaugmentation to be effective option to be explored especially in the developing parts of the world
\end{abstract}

Keywords: Biostimulation, Bioaugmentation, Strategy, Biodegradation \& Aviation Fuel

Aims Research Journal Reference Format:

Ogunsola, O.O. \& Adebusoye, S.A. (2018): Biostimulation and Bioaugmentation: The Strategy of Choice in the Biodegradation of Aviation Fuel. Advances in Multidisciplinary \& Scientific Research Journal. Vol. 4. No.2, Pp 25-

\section{INTRODUCTION.}

Generally, the quality of the environment inhabited by living things (that is water, air and soil) is closely related to the overall quality of life on the planet earth (Vidali, 2001). The development of petroleum industries have resulted in accidental and deliberate oil spillage which has reduced the quality of life. It has been shown that bioaugmentation and biostimulation are some of the efficient strategies that can be employed in the clean-up of aviation polluted soil. Bioaugmentation is the process by which indigenous or allochthonous wild type or genetically modified microorganisms are applied to polluted hazardous waste sites in order to accelerate the removal of undesired compounds (Mrozik and Piotrowska-Seget, 2010).

The capacity of bacteria to degrade crude oil is usually determined by their ability to transport the petroleum hydrocarbon into their cell (dependent largely on molecular size and water solubility). Also, the petroleum hydrocarbon has to be a suitable substrate for the available enzyme (Juhasz and Naidu, 2000). The dominant group of bacteria involved in biodegradation in oil spillage are hydrocarbonoclastic bacteria, their numbers increases in the case of oil spill. Of this group, Alcanivorax burkumensis can break down certain alkanes into harmless products and also produce a layer of biosurfactant around the cell to enhance oil emulsification. There are other groups of bacteria that help in the degradation of crude oil either independently or as consortia, examples are Pseudomonas aeruginosa, Bacillus subtilis, Acinetobacter Iwoffi (Al Wasify and Ahmed, 2004).

Bioaugmentation can be carried out using single strain or microbial consortia. The failure of single organisms to achieve complete degradation of high molecular weight hydrocarbons have resulted in the use of consortium of microorganisms in an attempt to achieve consistent degradation. In many cases, it has been presented that consortia were more effective than single strains by the fact that intermediates of a catabolic pathway of one strain may be further degraded by other strains possessing suitable catabolic pathway (Heinaru et al., 2005). Biostimulation itself is a difficult process which is affected by many environmental elements. It is a method used to manipulate the soil in such a way that biodegradation is stimulated and the reaction rates are increased, this include supplying the environment with nutrient such as nitrogen and phosphorus, with electron acceptors such as oxygen. (Iwamoto and Nasu, 2001). The purpose of biostimulation is to augment the activities of microorganisms indigenous to the soil that are capable of degrading pollutant from soil environment. 
The principle behind biostimulation is that when additional nutrient is added, microorganisms replicate, increase in number and thus increase the rate of biodegradation (Thiemann and Palladino, 2009). Combinations of inorganic nutrients often are more effective than single nutrient (Sutherland et al., 2000). The aim of this study is to compare the efficiency of biostimulation technique against bioremediation and to determine the best option in the bioremediation of hydrocarbon.

\section{MATERIALS AND METHOD}

\section{Microorganisms}

Bioaugmentation was carried out by seeding the polluted soil with isolated, characterized and known microorganisms and was collected on slants and stored at $4^{\circ} \mathrm{C}$. Two different species of bacteria Ralstonia sp. Strain SA4 and Pseudomonas sp. Strain SA6 were screened for their ability to degrade hydrocarbon. This was done by aseptically inoculating the organisms into separate conical flasks containing peptone water and were incubated at room temperature. The organisms were left to grow in the flask and the optical density was monitored using a spectrophotometer at $620 \mathrm{~nm}$ wavelength until the optical density one was attained.

To test the biodegradation potential of the organisms before use in this study, the organisms were then introduced into conical flasks containing $50 \mathrm{ml}$ MSM and $0.50 \mathrm{ml}$ aviation fuel. Control was set up in each case for the two organisms used. The control contained the same quantity of MSM and aviation fuel used for the experimental set up but without introducing any bacteria. The flasks were swirled daily and were observed for 14 days. At the end of the $7^{\text {th }}$ day, significant degradation was observed in the flasks as the content of each of the flasks grew turbid and emulsification was observed in the flasks. The control set up remained clear with no turbidity.

To determine the colony forming unit of the organisms introduced into the microcosm, Luria Barteni broth was inoculated with the screened organisms, incubated at room temperature and was monitored for 24 hours. At every 6 hours interval, readings of the optical density (OD) were taken using the spectrophotometer at $620 \mathrm{~nm}$ wavelength. Simultaneously, the total viable count (TVC) of the organisms was enumerated. From the result obtained, the log of the TVC was plotted against the log of OD to determine the colony forming units which were $1.5 \times 10^{4}$ for Ralstonia sp. Strain SA4 and $2 \times 10^{3}$ as respect Pseudomonas sp. Strain SA6. The Luria Barteni broth containing each of the organisms were washed, the pellets were dispensed in to distilled water and used in the bioaugmentation of the soil.

\section{Preparation Of Minimal Salt Medium Used For Biostimulation}

The Minimal Salt Medium (MSM) used contained the following salts:

$\mathrm{Na}_{2} \mathrm{PO}_{4}-2.13 \mathrm{~g} / \mathrm{l}$

$\mathrm{KH}_{2} \mathrm{PO}_{4}-1.30 \mathrm{~g} / \mathrm{l}$

$\mathrm{NH}_{4} \mathrm{Cl}-0.5 \mathrm{~g} / \mathrm{l}$

$\mathrm{MgSO}_{4} .7 \mathrm{H}_{2} \mathrm{O}-0.2 \mathrm{~g} / \mathrm{l}$

\section{Preparation Of Microcosms}

Some samples of soil were collected from the upper $20 \mathrm{~cm}$ of an agricultural soil of the University of Lagos biological garden. The colour of the soil was dark brown and consists of fine, medium, coarse and silty sand. The soil's particle sizes are stated as follows: sand $68 \%$, silt $31 \%$ and traces of fine gravel.

Also, it has 0 plasticity index and a coefficient of permeability of $3.14 \times 10^{-5} \mathrm{~m} / \mathrm{s}$. The soil had no history of contamination with aviation or other hydrocarbon products. The soil was air-dried for 14days and was sieved using $2.36 \mathrm{~mm}$ sieve

\section{Bioremediation Procedure}

Open trays of $6.32 \mathrm{~cm}$ (height) by $25.5 \mathrm{~cm}$ (breadth) and $30 \mathrm{~cm}$ (length) were used for microcosms. Two kilograms of soil was weighed into three different trays labelled A, B and C. The content of tray A was $2 \mathrm{~kg}$ of soil, $280 \mathrm{~g}$ of aviation fuel and $400 \mathrm{ml}$ of distilled water containing consortium of Ralstonia sp. Strain SA4 and Pseudomonas sp. Strain SA6. The purpose microcosm $A$ was to verify the contribution made to the aviation fuel polluted soil by the introduction of consortium of known microorganisms (bioaugmentation). Tray B contained $2 \mathrm{~kg}$ of soil, $280 \mathrm{~g}$ of aviation fuel, $200 \mathrm{ml}$ of distilled water and $200 \mathrm{ml}$ of MSM. This was designed to determine the contributions made to the clean-up of aviation fuel polluted soil by the addition of MSM to biostimulate the soil.

Tray $\mathrm{C}$ was the control experiment which included $2 \mathrm{~kg}$ of soil and $400 \mathrm{ml}$ of distilled water and was left uncontaminated with aviation fuel. This was meant to serve as the overall control to observe the physico-chemical and biological dynamics of the soil uncontaminated. The microcosms were contaminated with $280 \mathrm{~g}$ of aviation fuel so as to give $10.4 \%$ (v/w) pollution. 
The trays were kept in the laboratory at room temperature $\left(29^{\circ} \mathrm{C}\right)$ throughout the period of the analysis. They were watered every 7 days with sterile distilled water to maintain a moisture level of $25 \%$. Samples were taken at 5 -day interval for analysis (chemical analysis, microbiological analysis and gas chromatography).

\section{Physico-Chemical Analysis}

The soil physico chemistry was evaluated using standard analytical protocols. The total nitrogen, potassium and available phosphorus contents were determined according to Chopra and Kanwar, (1998). The pH of soil samples was monitored using pH meter (Jenway) according to Nwachukwu (2000).

\section{Aviation Oil Analysis}

The residual aviation fuel in the soil was determined according to Adebusoye et al. (2007). It was extracted from the from the soil sample $(5 \mathrm{~g})$ using $\mathrm{n}$-hexane: dichloromethane system $(1: 1)$ and quantified gravimetrically. The residual oil concentration was determined by gas chromatography a Hewlett Packard 5890 series II gas chromatograph equipped with flame ionization detector (FID) and $30 \mathrm{~m}$ long HP - 5 column (internal diameter, $0.25 \mathrm{~mm}$; film thickness, $0.25 \mu \mathrm{m}$ ). The carrier gas used was nitrogen.

\section{Microbiological Analysis}

The analysis of the total heterotrophic bacterial and fungal counts were carried out using the spread plate method and expressed as Cfu/g. In the case of total hydrocarbon-degrading bacterial and fungal counts, aviation fuel was supplied as the sole carbon and energy source through vapour phase transfer. The counts were also expressed in Cfu/g.

\section{Statistical Analysis}

Microsoft excel was used to calculate and plot the graph of log cfu/g against days. Also, the statistical analysis used was $\mathrm{t}$-test to determine whether there is significant depletion of aviation fuel in the microcosm from days 0 to 35 .

\section{RESULT}

\section{Microbial Population Dynamics}

Initial studies carried out on the soil sample on day 0 as compared with the studies carried out on the other days revealed that there was a decrease in the log cfu/g of the heterotrophic bacterial and fungal community between days 0 and 5 after which there was an increase in the population of the microflora between days 5 and 25 . The population count began to decline by day 30 in both the microcosms seeded and fortified with MSM.

Also, population of heterotrophic bacteria were observed to be higher than their fungal counterpart especially in the seeded microcosm with the highest average count of log cfu/g of 8.92 in heterotrophic bacteria and $5.72 \log \mathrm{cfu} / \mathrm{g}$ in heterotrophic fungal community. Similar development was observed in the log cfu/g of hydrocarbon utilizers.

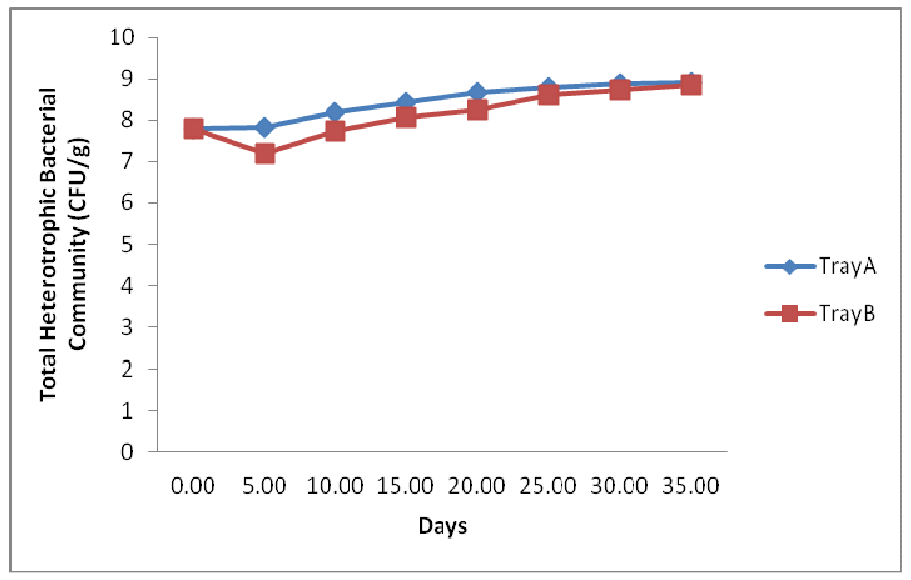

Figure 1: Total Heterotrophic Bacterial Community (CFU/g) 


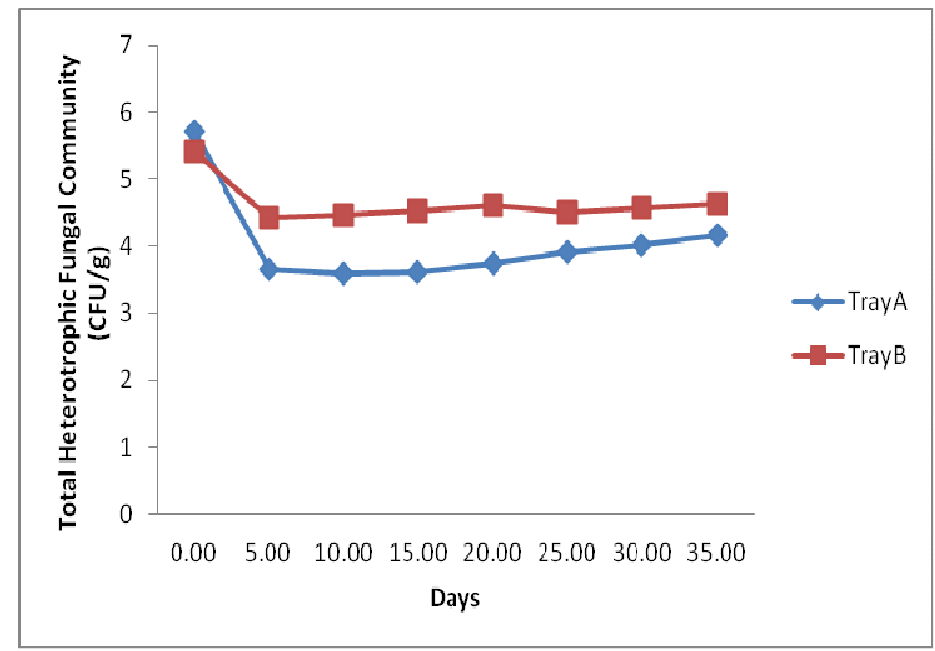

Figure 2: Total Heterotrophic Fungal Community (CFU/g)

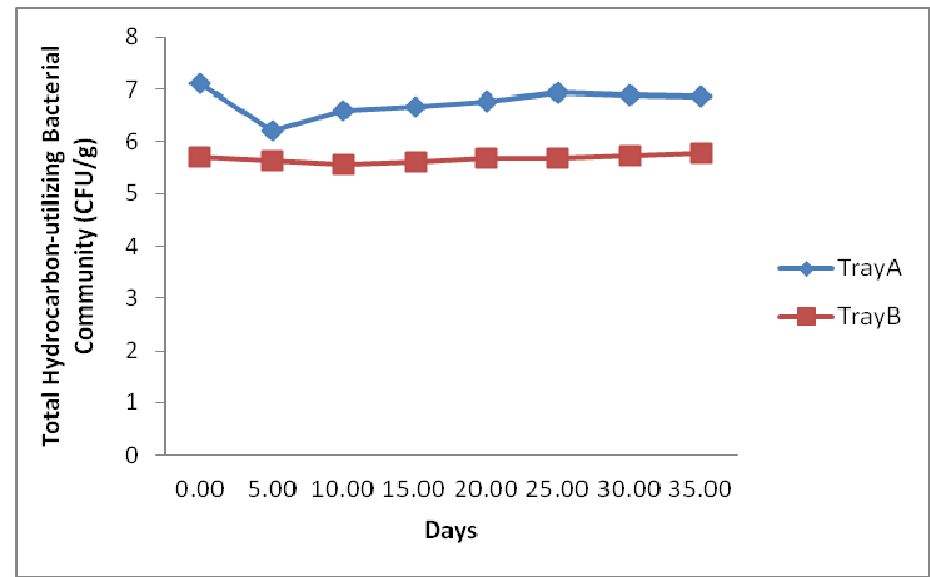

Figure 3: Total Hydrocarbon-Utilizing Bacterial Community

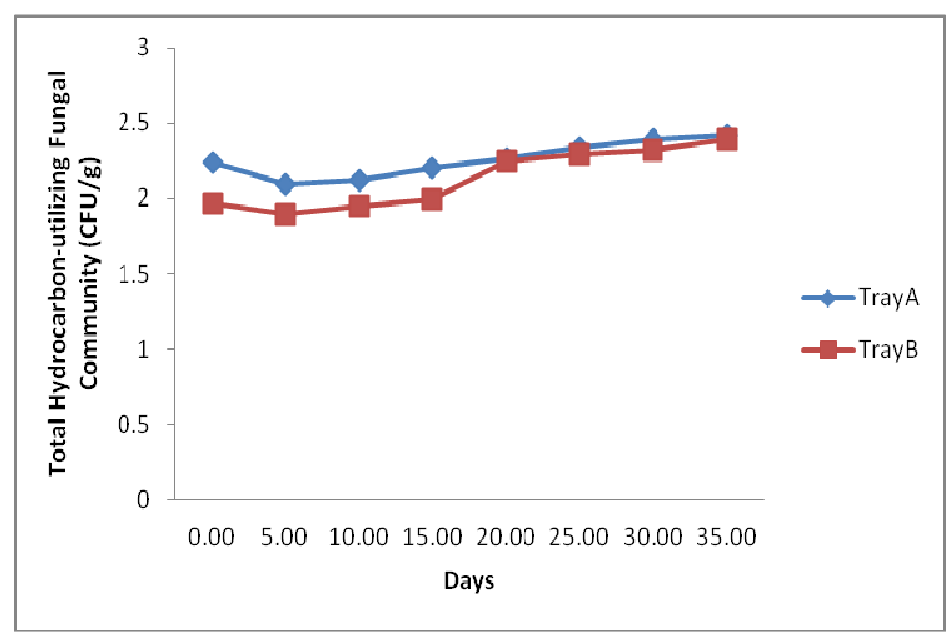

Figure 4: Total Hydrocarbon-Utilizing Fungal Community 


\section{Effect Of Fortification With Msm And Consortium Of Microorganisms}

The amendment of the microcosm exhibited a positive result as seen in the microbial population increase in the seeded and that fortified with MSM with the highest mean $\log \mathrm{CFU} / \mathrm{g}$ of 8.44 in heterotrophic bacterial populations of seeded microcosm. Impressively, the soil with the highest degradation rate documented an increase in the mean population counts of aviation fuel utilizing organisms from between days 5 and 25 in all of the set-ups polluted with aviation fuel.

\section{Physico-Chemistry Of The Soil}

A summary of the physico-chemical parameters of the experimental set-up is showed that the $\mathrm{pH}$ of the microcosm fortified by seeding the soil increase from between days 0 and 15 . On the other hand, the $\mathrm{pH}$ showed a slight reduction by day 35. In the soil fortified with MSM, pH increase was observed from days 0 to 35 .

Furthermore, there was increase in the nitrate, potassium and phosphate content of the soil fortified with MSM. The same trend was observed in the seeded microcosm except the phosphate content which showed some reductions from between days 0 and 35 .

\section{Aviation Oil Reduction Analysis}

The original concentration of the aviation fuel applied was $3762 \mathrm{mg} / \mathrm{kg}$ on day 0 for all the microcosms except the control. All the microcosm displayed a magnitude of reduction in the aviation oil content from between days 0 and 35 . The soil seeded with consortium of Ralstonia sp. Strain SA4 and Pseudomonas sp. Strain SA6, showed $80 \%$ degradation rate while that fortified with MSM showed $77 \%$ degradation rate. The chromatographic fingerprints revealed that the degradation rate of the soil amended with consortium of hydrocarbon degrading bacteria was higher than the soil treated with MSM.

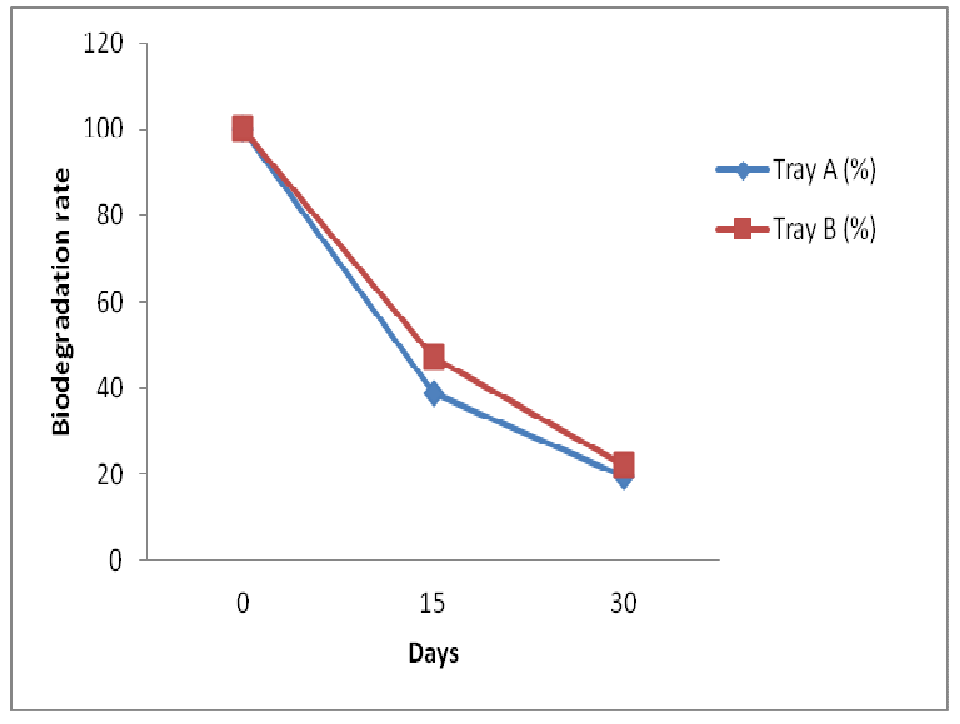

Figure 5: Biodegradation of Aviation Fuel 
Advances In Multidisciplinary

Pिis \& Scientific Research

Vol. 4 No. 2, June 2018

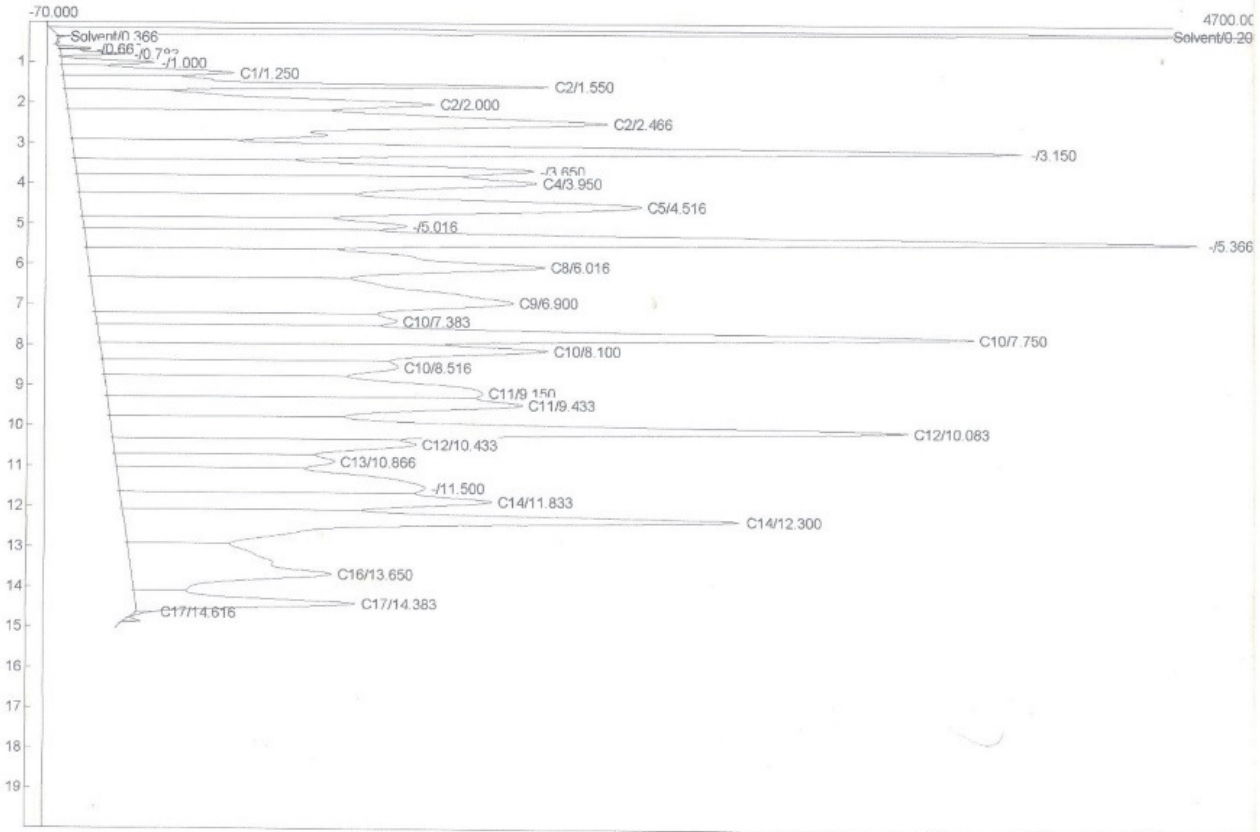

Figure 6: Day 0 of MSM fortified soil

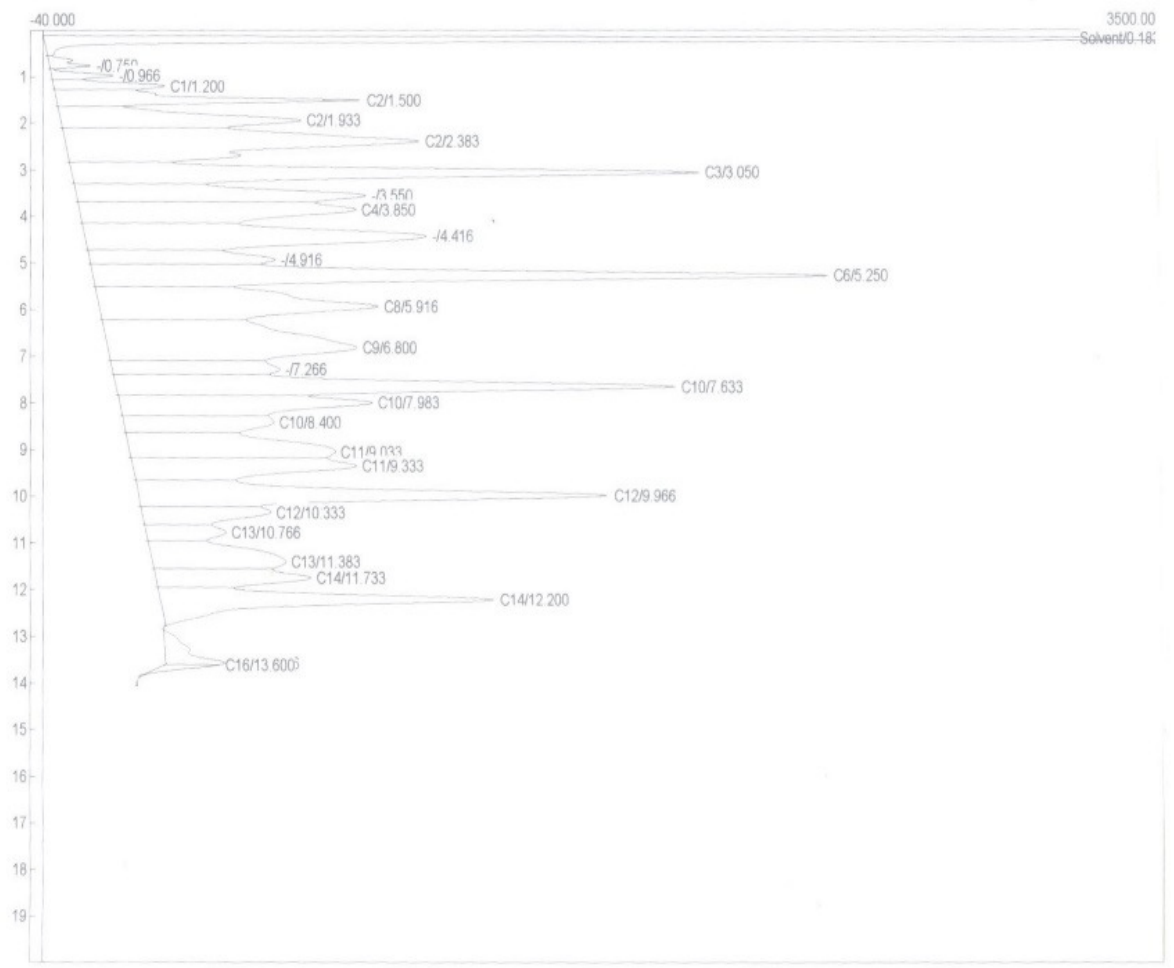

Figure 7: Day 15 of MSM fortified soil 
Advances In Multidisciplinary

A. Pus \& Scientific Research

Vol. 4 No. 2, June 2018

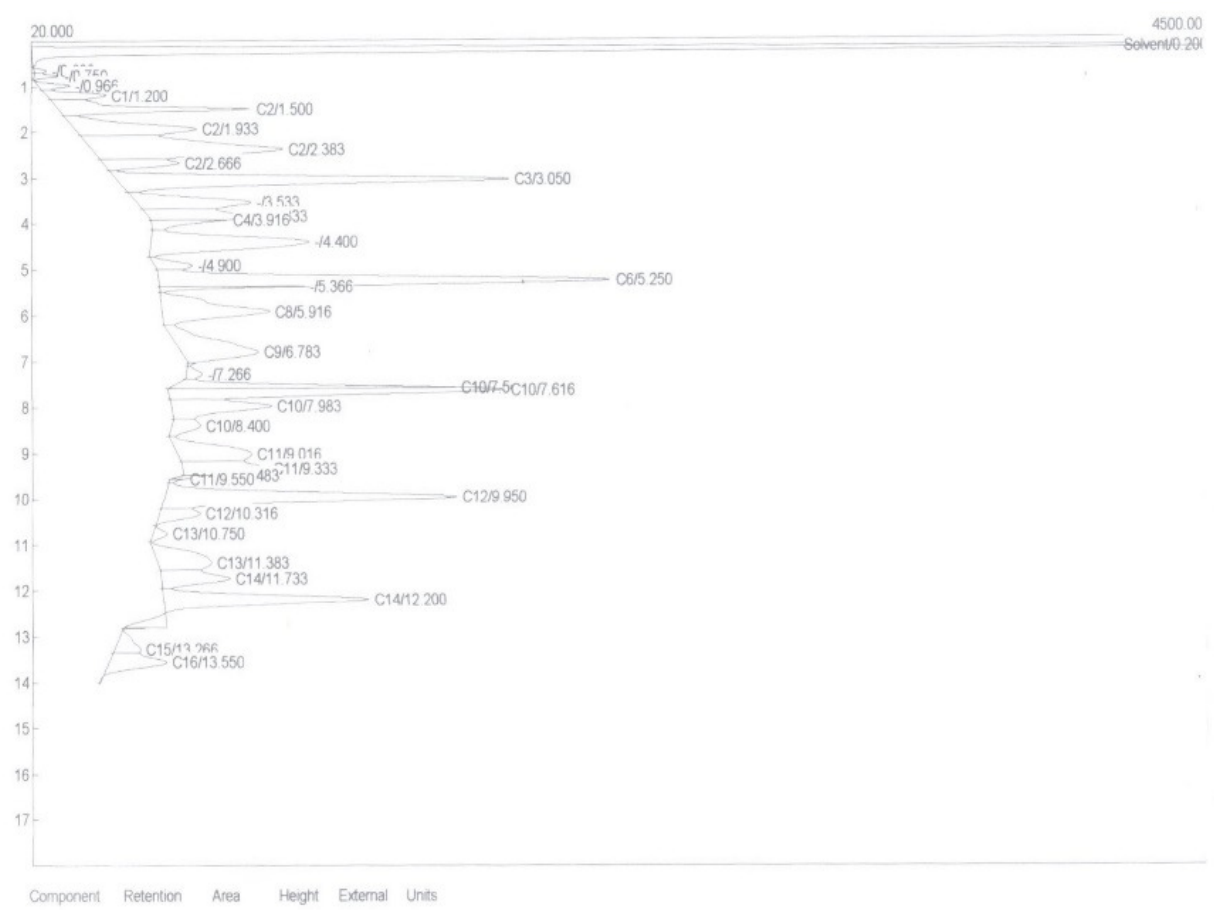

Figure 8: Day 30 of MSM fortified soil

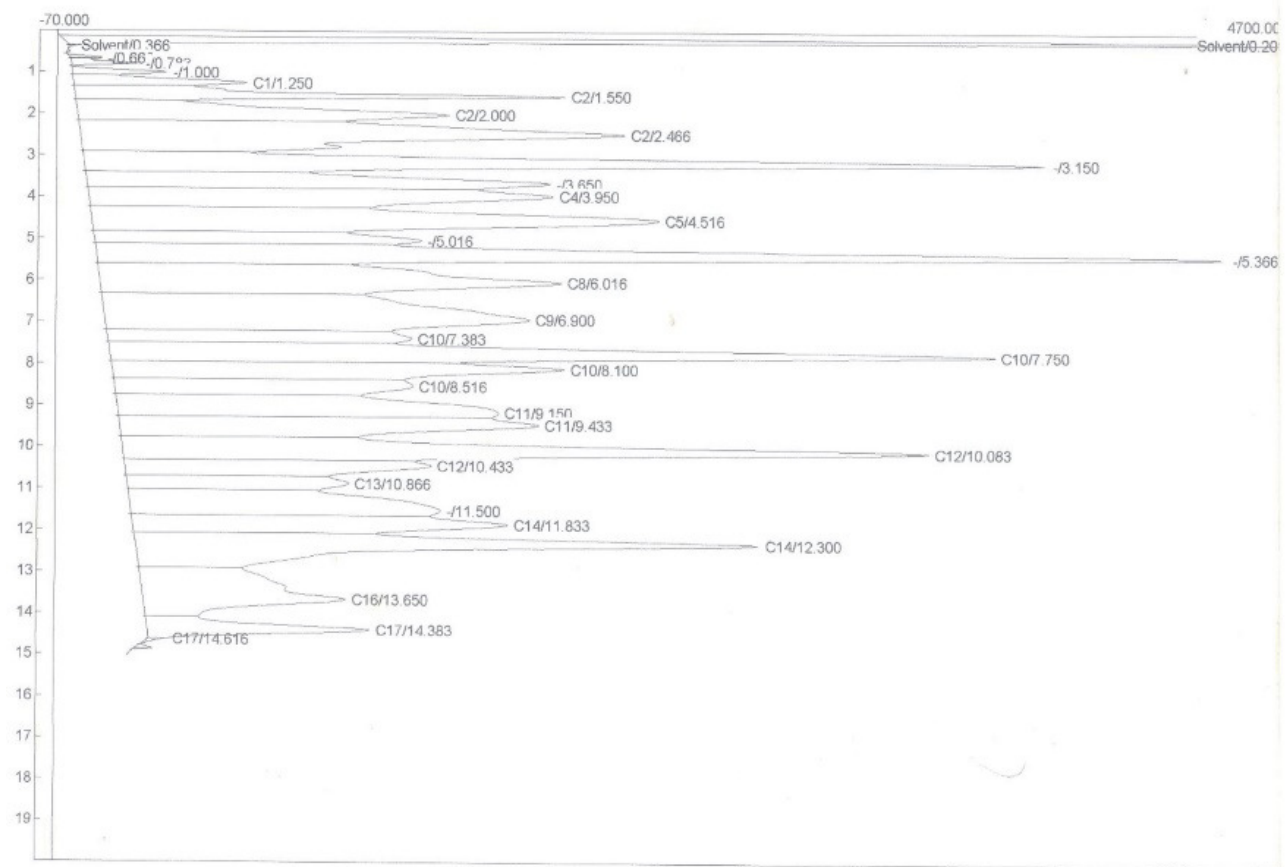

Figure 9: Day 0 of soil seeded with consortium of bacteria 
Advances In Multidisciplinary

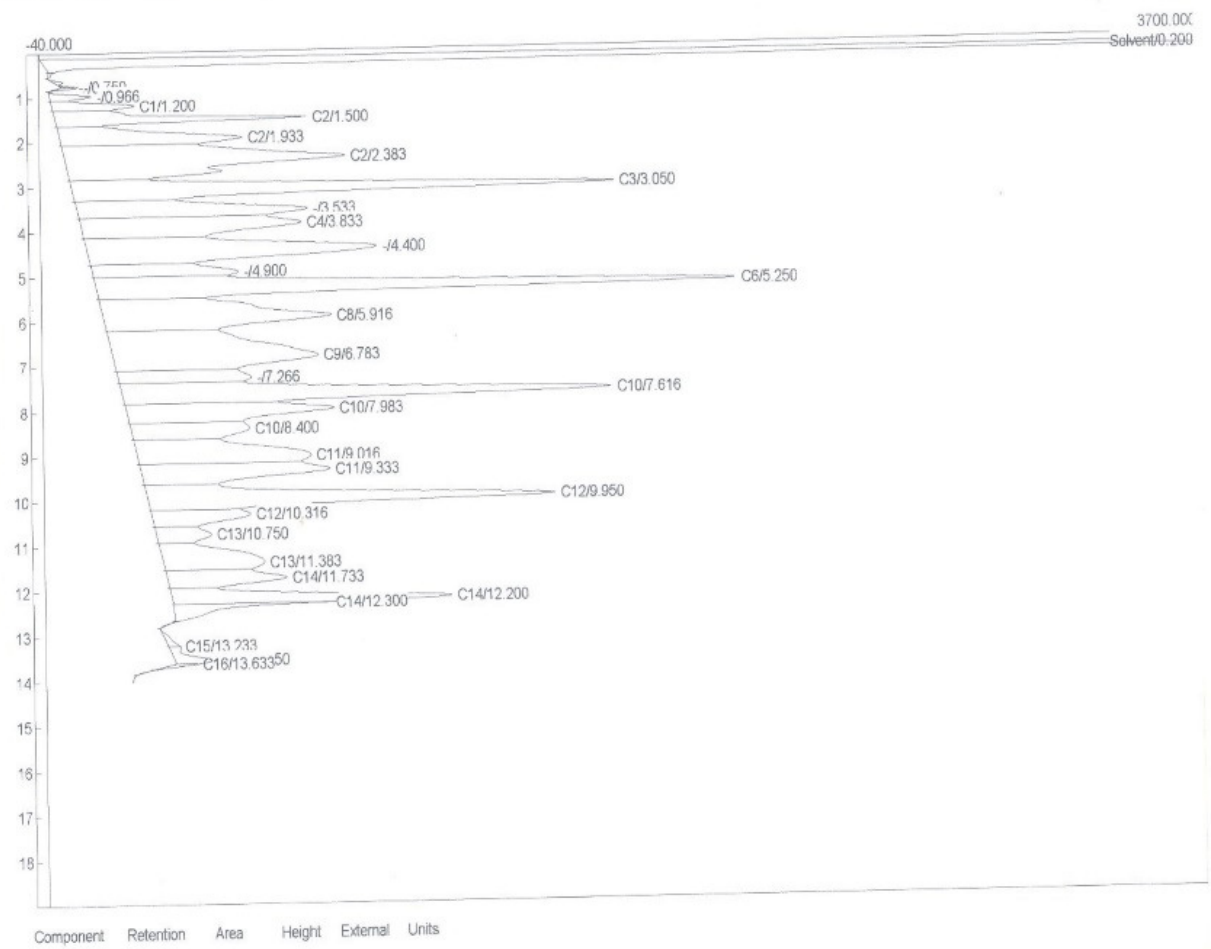

Figure 10: Day 15 of soil seeded with consortium of bacteria

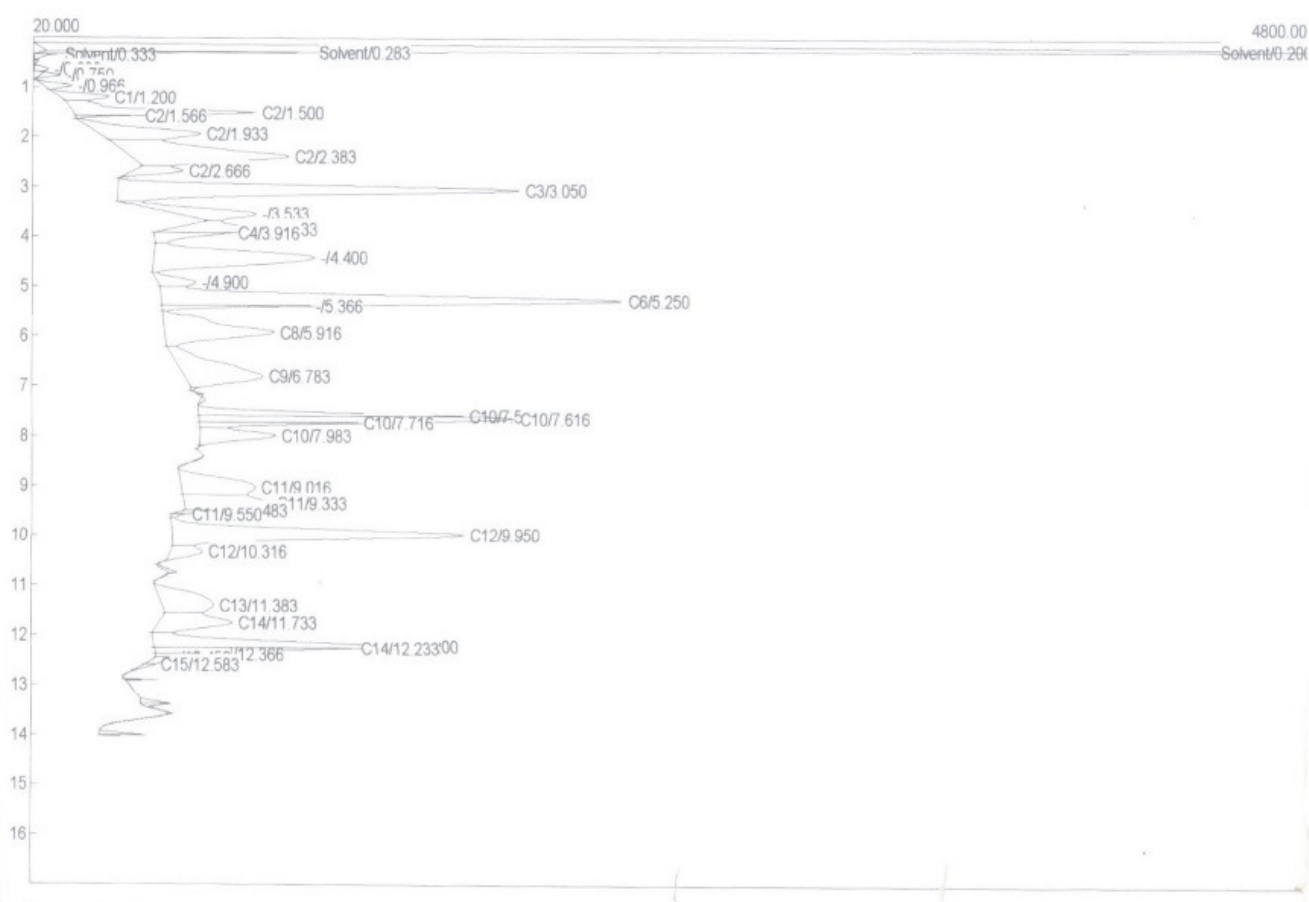

Figure 11: Day 30 of soil seeded with consortium of bacteria 


\section{DISCUSSION}

The widespread use of hydrocarbons over the years has resulted in problems caused by the interaction with biological systems in the environment. Considering the toxic effects of these hydrocarbons, it is therefore essential to remove these chemical pollutants from the environment. The use of biological method in the removal of these chemicals becomes the method of choice since microorganisms can use varieties of xenobiotic compounds including hydrocarbon for their growth, mineralization and detoxification (Kanekar et al., 2003). Proportional study of the two bioremediation strategies was investigated in this study with the aim of adding to the field of knowledge on the use of microorganism in the degradation of hydrocarbons. The decrease in bacterial and fungal counts from days 0 to 5 observed in trays $A$ and $B$ can be attributed to the toxic effects of the aviation fuel and this is in line with the studies carried out by Nwachukwu, 2001 and Umanu et al., 2013.

Amendment of both trays with MSM and consortium of Ralstonia sp. Strain SA4 and Pseudomonas sp. Strain SA6 showed a positive result and corroborates findings of several researchers that fortifying hydrocarbon polluted soil hastens the rate of biodegradation. Adebusoye et al., (2010) revealed that fortifying with cassava steep liquor can effectively aid degradation of diesel contaminated soil while Omotayo et al., (2012) fortified the soil with microorganisms like Micrococcus varians, Bacillus badius, Corynebacterium ulcerans and Corynebacterium amycolatum and biodegradation rate as high as $90.82 \%$ was recorded.

Bioremediation of hydrocarbon can occur by natural attenuation, biostimulation or bioaugmentation. There have been debates over the most efficient biodegradation strategies and many researchers have come up with different results. Several investigations have proved bioaugmentation to be an efficient strategy of bioremediation (Ueno et al., 2007 and Christopher and Christopher, 2004) and this is line with the report of this study which showed $80 \%$ degradation of aviation oil when bioaugmentation was used. It is also widely believed that the use of consortium is more effective than seeding with a lone microorganism. Individual microorganism could only metabolize limited range of hydrocarbon substrate. This has led to the assertion that mixed culture exhibited superior degradative competence than pure culture (Adebusoye et al., 2007) and that no single microbial species has the enzymatic ability to metabolize compounds found in hydrocarbon. In reality all strains will be working together to bring about the remedial action of the contaminated site (Okoh, 2006). This investigation also confirmed the effectiveness of seeding with consortium of hydrocarbon degraders as an effective bioremediation option. The consortium of known microorganisms utilized by this study had history of prior degradative ability. Pseudomonas spp is reputed to possess broad substrate affinity for different classes of hydrocarbons (Mandri and Lin, 2007) and Ralstonia spp also possess high ability to degrade petroleum hydrocarbons (Brooljmans et al., 2009).

However, studies have shown that bioaugmentation is not an effective approach in the decontamination of polluted sites. Kauppi et al (2011) reported that bacterial inocula did not advance soil remediation. This was attributed to the lack of competitive ability of the microbial inocula used with the soil bacteria. Similar result has also been reported by Thomassin-Lacroix et al (2012). Biostimulation MSM have also been investigated in this study with positive results. These findings are in agreement with the report of Roling et al (2001), who observed that the treatment of contaminated soil by adding nutrients was the fastest method of bioremediation. McKew et al (2007) also reported that biostimulation by the addition of nitrogen and phosphorus alleviates nutrient limitation and is an effective strategy for enhanced oil degradation. Biostimulation can also enhance degradation by inducing enzymes responsible for degradation (Cosgrove et al., 2010). However, it has been reported that added nutrients had no effect on the decontamination of polluted sites (Seklemova et al., 2001) and that extensive nutrient addition may be harmful to microbes and may result in slow degradation (Peltola et al., 2006). This study has shown the effectiveness of fortifying the soil in the clean-up of aviation fuel pollution as it speeds up the rate at which degradation of xenobiotic substances occur.

\section{CONCLUSION}

This research is important as there is a case of oil spillage in the Niger delta area of Nigeria and some other parts of the country and the world. Adopting the method of bioremediation by bioaugmentation especially using consortium of bacteria and addition of nutrients to fortify the soil is cheap and environmentally friendly.

\section{REFERENCES}

1. Adebusoye, S.A., Ilori, M.O., Amund, O.O., Teniola, O.D. and Olatope S.O. (2007). Microbial degradation of petroleum hydrocarbons in polluted tropical stream. World J. Microbiol. 23: 1149-1159

2. Adebusoye, S.A., Ilori, M.O., Obayori, O.S., Oyetibo, G.O., Akindele, K.A and Amund, O.O. (2010). Efficacy of steep liquor for bioremediation of diesel-oil contaminated tropical agricultural soil. Environ. 30: 24-30 
3. Akinde, S.B. and Obire, O. (2008). Aerobic Heterotrophic Bacteria and Petroleum Utilizing Bacteria from Cow Dung and Poultry Manure. World J. Microbiol. Biotechnol. 24: 1999- 2002.

4. Al-Wasify, R. S. And Hamed, S.R. (2014).Bacterial degradation of crude oil using local isolates. Inter. J. Bacteriology. 2: 1-8.

5. Brooljmans, R.J., Pastlink, M.I. and Slezen, R.J. (2009). Hydrocarbon-degrading bacteria: the oil spill clean-up crew. Microb. Biotechnol. 2(6): 587-594

6. Chopra, S.I. and Kanwar, J.S. (1998). Analytical agricultural chemistry. MacMillian Press, London.

7. Christopher, W.K and Christopher, L.K. (2004). Bacterial succession in petroleum land treatment unit. Appl. Environ. Microbiol. 70(3): 1777-1785

8. Cosgrove, L., McGeechan, P.L., Handley, P.S. and Robson, G.D. (2010). Effect of biostimulation and bioaugmentation on degradation of polyurethane buried in soil. Appl. Environ. Microbiol. 76(3): 810-819

9. Heinaru, E., Merimaa, M., Viggor, S., Lehiste, M., Leito, I. and Truu, J. (2005). Biodegradation efficiency of functionally important population selected for bioaugmentation in phenol- and oil-polluted area. FEMS Microbiol Ecol. 51: 363-373

10. Iwamoto, T. and Nasu, M. (2001). Current bioremediation practice and perspective. J. Biosci. Bioeng. 92(1): 1-8

11. Juhasz, A.L. and Naidu, R. (2000). Bioremediation of high molecular weight polycyclic aromatic hydrocarbons: a review of the microbial degradation of benzo-pyrene. Inter. Biodeterior. Biodegrad.45, 57- 88.

12. Kauppi, S., Sinkkonem, A. and Romantschuk, M. (2011). Enhancing bioremediation of diesel-fuel contaminated soil in boreal climate. Comparison of biostimulation and bioaugmentation. Inter. Biodeterior. Biodegrad. 65: 359368.

13. Mandri, T. and Lin, J. (2007). Isolation and characterization of engine oil degrading indigenous microorganisms in Kwazulu-Natal, South Africa. Afri. J. Biotechnol. 6(1): 23-27.McKew, B.A., Coulon, F., Yakimov, M.M., Denavo, R., Genovese, M., Smith, C.J., Osborne, A.M., Timmis, K.N. and McGenity, T.J. (2007). Efficacy of intervention strategies for bioremediation of crude oil in marine systems and effect on indigenous hydrocarbonolistic bacteria. Environ. Microbiol. 9(6): 1562-1571

14. Mrozik, A. and Piotrowska-Seget, Z. (2010). Bioaugmentation as a strategy for cleaning up of soils contaminated with aromatic compounds. Microbiol. Research 165: 363-375

15. Nwachukwu, S.C.U. (2000). Enhanced rehabilitation of tropical aquatic environments polluted with crude petroleum using Candida subtilis. J. Environ. Biol. 21(3): 241-250.

16. Nwachukwu, S.C.U. (2001). Bioremediation of sterile agricultural soils polluted with crude petroleum by application of the soil bacterium Pseudomonas putida, with inorganic nutrient supplements. Curr. Microbiol. 42:231-236

17. Okoh, A.I. (2006). Biodegradation alternative in the clean-up of petroleum hydrocarbon pollutants. Biotechnol Mol. Biol. Rev. 1(2): 38-50

18. Omotayo, A.E., Ojo, O.Y. and Amund, O.O. (2012). Crude oil degradation by microorganisms in soil composts. Research J. Microbiol. 7(4): 209-218

19. Peltola R., Salkinoja-Salonen, M., Pulkkinem, J., Koivunem, M., Turpeinem, A.R., Aarnio, T. and Romanschuk M. (2006). Nitrification in polluted soil fertilized with fast and slow releasing nitrogen: a case study at refinery farming site. Environ. Poll. 143: 247-253.

20. Rolling, W.F., Milner, M.G., Jones, D.M., Lee, K., Daniel, F., Swannell, R.J. and Head, I.M. (2002). Robust hydrocarbon degradation and dynamics of bacterial communities during nutrient-enhanced oil spill bioremediation. Appl. Environ. Microbiol. 68(11): 5537-5548

21. Seklemova, E., Pavlova, A. and Kovachera, K. (2001). Biostimulation-based bioremediation of diesel fuel: field demonstration. Biodegrad. 12: 311-316

22. Sutherland, T.D., Horne, I., Lacey, M.J., Harcourt, R.L., Russell, R.J. and Oakeshott, J.G. (2000). Enrichment of an endosulfan-degrading mixed bacterial culture. Appl Environ. Microbiol. 66: 2822-2828

23. Thiemann, W.J. and Palladino, M.A. (2009). Introduction to biotechnology, $2^{\text {nd }}$ edition. Pearson, New York, pp. 209-222.

24. Thomassin-Lacroix, E.J.M., Eriksson, M., Reimer, K.J. and Mohn, W.W. (2002). Biostimulation and bioaugmentation for on-site treatment of weathered diesel fuel in artic soil. Appl. Microbiol. Biotechnol. 59: 551556.

25. Ueno, A., Ito, Y., Yumoto, and Okuyama, H. (2007). Isolation and characterization of bacteria from soil contaminated diesel oil and the possible use of these in autochthonous bioaugmentation. World J. Microbiol, Biotechnol. 23: 1739-1745

26. Umanu, G., Akpe, A.R. and Omoikhudu, A.R. (2013). Oil Degradation assessment of bacteria isolated from motor oil contaminated soils in Ota, Nigeria. I.J.A.B.R. 3(4): 506-513

27. Vidali, M. (2001). Bioremediation: An overview. Pure Appl. Chem. 73: 1163-1172 